\title{
Oyster larvae as a potential first feed for small-mouthed ornamental larval fish
}

\author{
Alexander J. Basford*, Benjamin Mos, Tomoki Mishina, Symon A. Dworjanyn
}

National Marine Science Centre, Southern Cross University, Coffs Harbour, NSW 2450, Australia

\begin{abstract}
Aquaculture of ornamental marine fish for the aquarium trade is a possible solution to the negative environmental impacts of wild collection. An impasse to the culture of many marine fish species is high larval mortality due to unsuitable live feeds. Common live feeds can be too large for ornamental species, which often have larvae with small mouths. We tested wild oyster larvae as an alternative live feed for first-feeding blue tang Paracanthurus hepatus. $P$. hepatus readily consumed oyster larvae but did not consume rotifers. Survival and growth of $P$. hepatus fed oyster larvae was similar to unfed controls, likely due to the oyster trochophores developing into indigestible veligers. Restricting the diet of $P$. hepatus to only oyster trochophores improved survival and eye development, but survival rates remained low. Oyster trochophores were conditioned in $\mathrm{pH} 4.8$ seawater to compromise their aragonite shells, and P. hepatus fed these had higher survival at $5 \mathrm{~d}$ post-hatch (dph) compared to those fed untreated trochophores and were the only fish surviving to $10 \mathrm{dph}$. The high consumption rates of oyster larvae by $P$. hepatus highlight the potential for bivalve larvae to be used as live feeds for first-feeding larval fish. Further research into improving the nutritional value of oyster larvae for larval fish may improve their viability as first feeds.
\end{abstract}

KEY WORDS: Acidification - Blue tang - Paracanthurus hepatus - Fatty acids - Live feeds · Larval rearing

\section{INTRODUCTION}

The collection of ornamental marine fish for the aquarium trade can cause negative environmental impacts, including decreased biodiversity from overextraction and damage to habitats from destructive fishing practices (Lecchini et al. 2006, Calado et al. 2017). For a growing marine aquarium trade to be sustainable, a greater reliance on cultured fish is essential. A key impasse to the commercialisation of many marine fish species is high mortality during the early larval stage due to a lack of suitable live feeds (Yúfera \& Darias 2007, Hamre et al. 2013). Poor first feeds are a common cause of mortality because larval fish have small energy reserves, high metabolic demands, and limited capacity to capture and digest food (Fisher et al. 2007, Yúfera \& Darias 2007, Rønnestad et al. 2013). These limitations appear exacerbated in small fish larvae as they are more sus-

\footnotetext{
*Corresponding author: alex.basford@scu.edu.au
}

ceptible to starvation and mortality during the larval stage compared to their larger counterparts (Miller et al. 1988, Pepin 1991, Olivotto et al. 2017).

The early larval stages of many species of marine fish consume only live prey (Dhont et al. 2013). Fish larvae frequently reject artificial diets because movement is required to trigger their feeding response (Langdon 2003, Conceição et al. 2010). Food must also be small enough to be ingested. Fish larvae are only able to capture prey that is $25-60 \%$ of their mouth gape (Shirota 1970, Fernández-Díaz et al. 1994, Østergaard et al. 2005). The 2 most common live feeds used in aquaculture, rotifers Brachionus spp. and brine shrimp Artemia spp., are often too large for fish larvae that have small mouth gapes $(<200 \mu \mathrm{m})$, such as the early larval stages of acanthurids, chaetodontids, pomacanthids, and some serranids (Nagano et al. 2000a,b, Su et al. 2005, Moorhead \& Zeng 2010). A lack of live feeds suited to fish larvae with small mouth

() The authors 2019. Open Access under Creative Commons by Attribution Licence. Use, distribution and reproduction are unrestricted. Authors and original publication must be credited. 
gapes is an impediment to closing the lifecycle of many commercially important fish species (Holt 2003).

Attempts to develop live feeds suited to larvae with small mouths have focused on copepod nauplii and, to a lesser extent, ciliates (Nagano et al. 2000a, Støttrup 2000, Olivotto et al. 2005, Ajiboye et al. 2011). Both copepod nauplii and ciliates have the appropriate size $(20-90 \mu \mathrm{m})$ for consumption by small larval fish (Nagano et al. 2000a, McKinnon et al. 2003). Copepod nauplii are highly nutritious and, when fed to marine fish larvae, improve fish survival and growth compared to common live feeds such as rotifers (Hamre et al. 2008, Olivotto et al. 2008, Karlsen et al. 2015, Zeng et al. 2018). Recent breakthroughs in closing the lifecycles of some ornamental fish species have been facilitated using copepod nauplii as live feeds (DiMaggio et al. 2017, Callan et al. 2018). However, the difficulty and high cost of producing copepods constrains their use in commercial aquaculture (Alajmi \& Zeng 2014, Kline \& Laidley 2015, Franco et al. 2017). Conversely, ciliates can be easily cultured at high densities but are not nutritious enough to support high larval fish survival (Nagano et al. 2000a,b, Olivotto et al. 2005, de Freitas Côrtes et al. 2013, Leu et al. 2015). The limitations of copepods and ciliates in aquaculture highlight the need to assess the suitability of other small invertebrates as live feeds.

Oyster larvae may be a suitable live feed for smallmouthed fish larvae due to their small size, nutritional profile, and the ease of producing large numbers with minimal cost. Trochophores and early veligers of oyster species such as the cosmopolitan Crassostrea gigas and Australasian Saccostrea glomerata are similar in size (50-70 $\mu \mathrm{m})$ to ciliates and copepod nauplii (Table 1). Many oysters are highly fecund, with each female producing millions of eggs (Davis \& Chanley 1956, Gallager \& Mann 1986, O'Connor et al. 2008). Oysters provision their larvae with high levels of the nutrients that are required by larval fish, including protein and polyunsaturated fatty acids (PUFAs) as both neutral lipids and phospholipids (Chu \& Webb 1984, Massapina et al. 1999, Soudant et al. 1999, Caers et al. 2002). Oyster and other bivalve veligers are consumed by fish larvae in the wild and in captivity (Howell 1979, Harding 1999, Cabrera \& Hur 2001, Harding et al. 2015, Nack et al. 2015), although survival rates of fish larvae fed oysters vary considerably among species (0-80\%) (Howell 1979, Watanabe et al. 1996, Cabrera \& Hur 2001). Further research is required to fill knowledge gaps about the potential of oyster larvae as live feeds for many types of fish, such as the larvae of marine ornamental finfish (Oliver et al. 2017).
There is growing interest in developing larval rearing protocols for ornamental fish to offset destructive wild collection (Lecchini et al. 2006, Calado et al. 2017). Many of the fish families that dominate the ornamental trade-Acanthuridae, Pomacanthidae, and Chaetodontidae - have larvae with small mouth gapes and cannot be reliably sourced from aquaculture. Of these fishes, the blue tang Paracanthurus hepatus is among the most popular and widely traded, but consumer demand is met completely by wild collection (Militz \& Foale 2017, Rhyne et al. 2017). Although there has been some success in closing the lifecycle of $P$. hepatus, high mortality rates during the early larval stage results in few larvae reaching the juvenile stage (Ho et al. 2013, Calado 2017, DiMaggio et al. 2017). Improving the efficacy of live feeds is a key step to overcoming the bottleneck during the early larval stage of $P$. hepatus (DiMaggio et al. 2017).

In this study, we examined the use of oyster larvae as a first feed for small-mouthed larval fish, using $P$. hepatus as a model species. We first tested whether $P$. hepatus consume oyster larvae, and compared growth and survival of $P$. hepatus fed rotifers or oyster larvae. To understand whether different stages of oyster larvae varied in their value as first feeds, we compared the growth and survival of $P$. hepatus fed oyster trochophores that were allowed to develop into the veliger stage with fish larvae fed only trochophores. Finally, in an attempt to improve the digestibility of oyster trochophores, we conditioned them in acidic water to reduce their calcification and compared the survival of $P$. hepatus fed these versus regular oyster trochophores.

\section{MATERIALS AND METHODS}

\subsection{Paracanthurus hepatus broodstock}

Larval $P$. hepatus were obtained from 9 broodstock housed at the National Marine Science Centre, New South Wales (NSW), Australia (30¹6.05' S, $\left.153^{\circ} 08.25^{\prime} \mathrm{E}\right)$. Broodstock were held in an indoor 70001 recirculating tank at $27.5-29^{\circ} \mathrm{C}, \mathrm{pH} 8-8.1$, 35 ppt salinity, and given a simulated natural photoperiod. Broodstock were fed daily with a mixed diet of commercial pellets (API ${ }^{\circledR}$ Tropical Pellets, Mars; Hikari Marine-A ${ }^{\circledR}$, Hikari Seaweed Extreme ${ }^{\mathrm{TM}}$, Kyorin Food Industries) and dried seaweed Porphyra sp. Broodstock spawned naturally, and floating fertilized eggs were collected overnight in a $50 \mathrm{l}$ egg collector for use in experiments. 


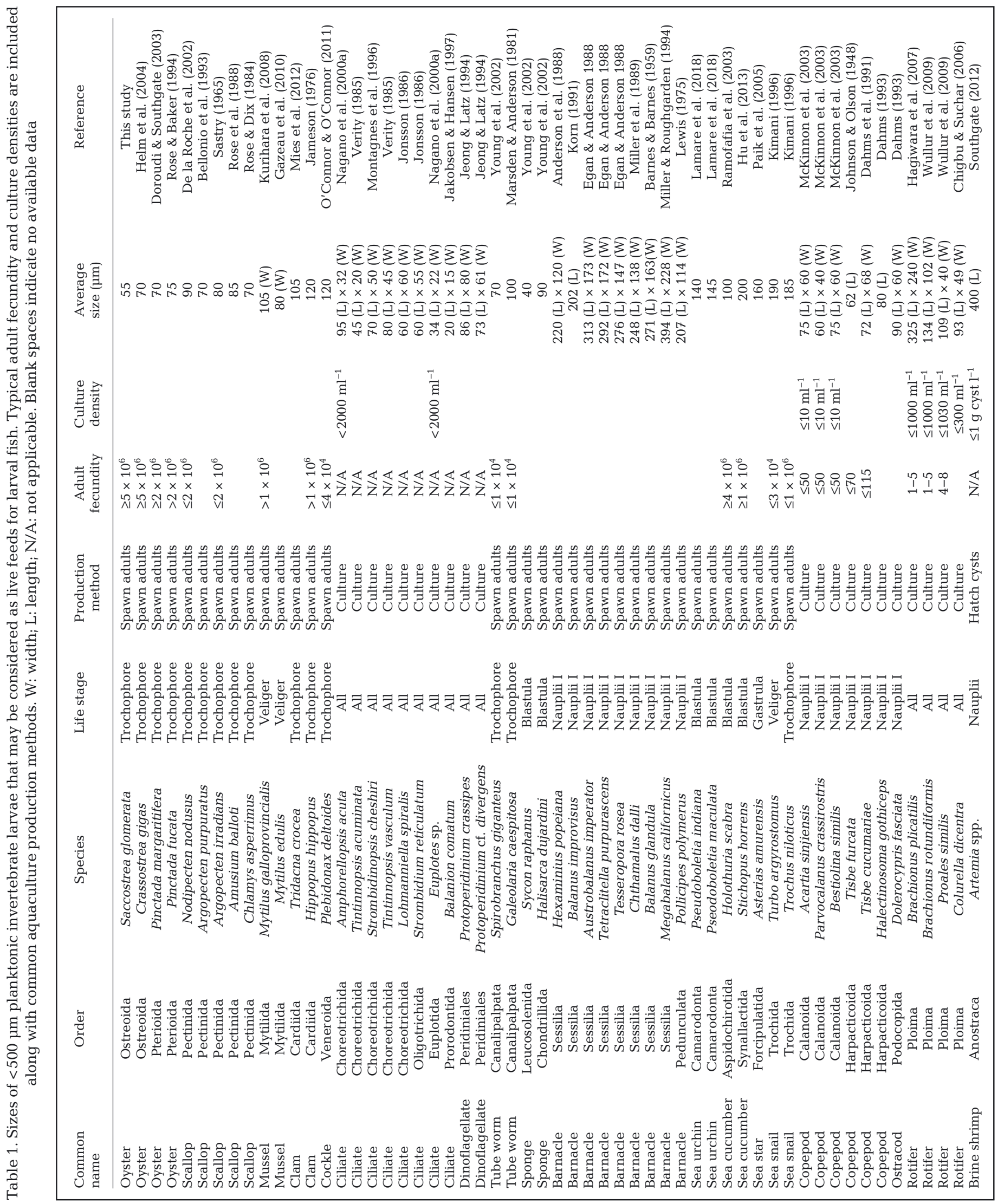




\subsection{Effects of live feeds on growth and survival of $P$. hepatus}

During January 2018, fertilized eggs were transferred from the egg collector to a 121 aerated incubation tank provided with $0.21 \mathrm{~min}^{-1}$ flow-through seawater (filtered to $1 \mu \mathrm{m}$ and UV-treated; hereafter FSW), and incubated at $27.5-28^{\circ} \mathrm{C}$. At $24 \mathrm{~h}$ posthatch, $P$. hepatus larvae were stocked into 121 cylindrical black plastic tanks at a density of 100 larvae tank $^{-1}$. Abnormal larvae that could not maintain their position in the water column or were swimming erratically were not used in experiments.

Experimental tanks were kept in heated water baths to maintain a water temperature of $27.5-28^{\circ} \mathrm{C}$. Each tank was fitted with a $50 \mathrm{~mm} \varnothing$ banjo screen with $250 \mu \mathrm{m}$ mesh that maintained the water volume at $12 \mathrm{l}$ and an airstone providing very fine aeration. Tanks were provided with $0.1 \mathrm{l} \mathrm{min}^{-1}$ flow-through FSW until the larvae had developed the ability to feed exogenously at $3 \mathrm{~d}$ post-hatch (dph). Water quality parameters during experiments were always within $\mathrm{pH} 8.0-8.1,>7.5 \mathrm{mg} \mathrm{l}^{-1}$ dissolved oxygen, and 35.0-36.0 ppt salinity, measured in all tanks daily using a Hach HQ40d multi-controller fitted with a Hach PHC101 temperature-compensated pH probe, a Hach LDO101 probe, and a Hach CDC101 conductivity probe. The photoperiod was $12 \mathrm{~h}$ light:12 h dark, with a light intensity of $2000 \mathrm{~lx}$ at the level of the tanks.

Rotifers (Brachionus sp., S-strain, Port Stephens Fisheries Institute) were cultured in 2 identical 2001 black fibreglass tanks filled with $28^{\circ} \mathrm{C}, 35$ ppt salinity FSW. Each tank of rotifers was fed $50 \mathrm{ml}$ of Nanno 3600 (Instant Algae ${ }^{\circledR}$, Reed Mariculture) daily and were maintained at a density of 100-150 $\mathrm{ml}^{-1}$. Oxygen saturation was kept above $7.5 \mathrm{mg} \mathrm{l}^{-1}$ and $20 \%$ of the volume of each tank was exchanged daily. Rotifers were harvested from each tank on alternate days. Rotifers $($ mean $\pm \mathrm{SE}$ length $=191.5 \pm 2.3 \mu \mathrm{m}$, width $=150.2 \pm$ $8.2 \mu \mathrm{m}, \mathrm{n}=50$ ) were washed with FSW in a $45 \mu \mathrm{m}$ wet sieve before being fed to larval $P$. hepatus.

A total of 60 adult Sydney rock oysters Saccostrea glomerata were sourced from a commercial producer at Urunga, NSW, $3 \mathrm{~d}$ before each experiment and maintained in tanks containing 251 of $25-26^{\circ} \mathrm{C}$ flowthrough seawater. Each tank was fed $10 \mathrm{ml}$ of Pavlova sp. algal paste (Pavlova 1800, Instant Algae ${ }^{\circledR}$, Reed Mariculture) daily, during which water flow was stopped for $3 \mathrm{~h}$.

Natural spawning could not be induced, so multiple ripe female and male oysters were strip-spawned as required. Eggs were pooled in a 51 beaker filled with $0.5 \mu \mathrm{m}$ FSW. Pooled sperm was added incrementally and fertilization checked microscopically. When $>90 \%$ of eggs had been fertilized, as evidenced by a fertilization envelope, embryos were added to a cylindro-conical culture tank containing $150 \mathrm{l}$ of gently aerated FSW $\left(25-26^{\circ} \mathrm{C}\right)$ for $\sim 10 \mathrm{~h}$ to develop to the trochophore stage. Immediately before feeding to $P$. hepatus larvae, oyster trochophores (diameter $=52.6 \pm 0.3 \mu \mathrm{m}, \mathrm{n}=50$ ) were washed in a $15 \mu \mathrm{m}$ wet sieve and counted. When trochophores were required for multiple feeds throughout the day (see Section 2.2.5), trochophores were held in FSW at $4^{\circ} \mathrm{C}$ for up to $8 \mathrm{~h}$ in an aerated $1 \mathrm{l}$ cylindro-conical bottle. This halted the development of the trochophores without causing mortality. Oysters held at $4^{\circ} \mathrm{C}$ were acclimated at $\sim 27^{\circ} \mathrm{C}$ for $10 \mathrm{~min}$ prior to feeding.

To test the effectiveness of oyster larvae and rotifers as live feeds for newly hatched $P$. hepatus larvae, tanks were randomly assigned to 1 of 4 diet treatments, with 3 replicates treatment ${ }^{-1}$. The 4 diets were oyster trochophores $\left(15 \mathrm{ml}^{-1}\right)$, rotifers $\left(5 \mathrm{ml}^{-1}\right)$, rotifers and oyster trochophores ( 3 and $10 \mathrm{ml}^{-1}$, respectively), and an unfed control. P. hepatus were fed once at the beginning of each light cycle until $5 \mathrm{dph}$. Prey densities were varied so the biomass among treatments were similar. All tanks were inoculated with live Nannochloropsis oculata at a density of $3 \times 10^{5}$ cells $\mathrm{ml}^{-1}$ to improve prey contrast and reduce phototaxism (Cobcroft et al. 2012). Tanks were flushed during each dark cycle with $27^{\circ} \mathrm{C}$ FSW at a rate of $0.1 \mathrm{l}$ $\mathrm{min}^{-1}$ to remove all remaining live feeds, algal cells, and waste. No water exchange occurred during the light cycle.

At 3 and 5 dph, 5 larval P. hepatus were removed from each replicate $6 \mathrm{~h}$ after the beginning of the light cycle, anaesthetized (1 ppm AQUI-S ${ }^{\circledast}$, New Zealand Ltd), placed on a stage micrometer, and photographed using an Olympus DP26 camera mounted on a stereo microscope. If fewer than 5 larvae remained in a replicate, all fish were sampled. ImageJ $1.51 \mathrm{j} 8$ imaging software was used determine whether live feeds had been consumed by measuring the prey incidence and gut area of $P$. hepatus larvae. Prey incidence is expressed as the percentage of larvae that had material in the gut (Pereira-Davison \& Callan 2018) (Fig. 1). Notochord length, body depth, and eye diameter were also measured from photographs of the $5 \mathrm{dph} P$. hepatus larvae (Thépot et al. 2016). Survival rates of $P$. hepatus larvae were determined at $5 \mathrm{dph}$ by counting the remaining fish in each replicate and are reported as a percentage of the larvae initially stocked to each replicate tank minus the 5 fish removed from each replicate at $3 \mathrm{dph}$. 


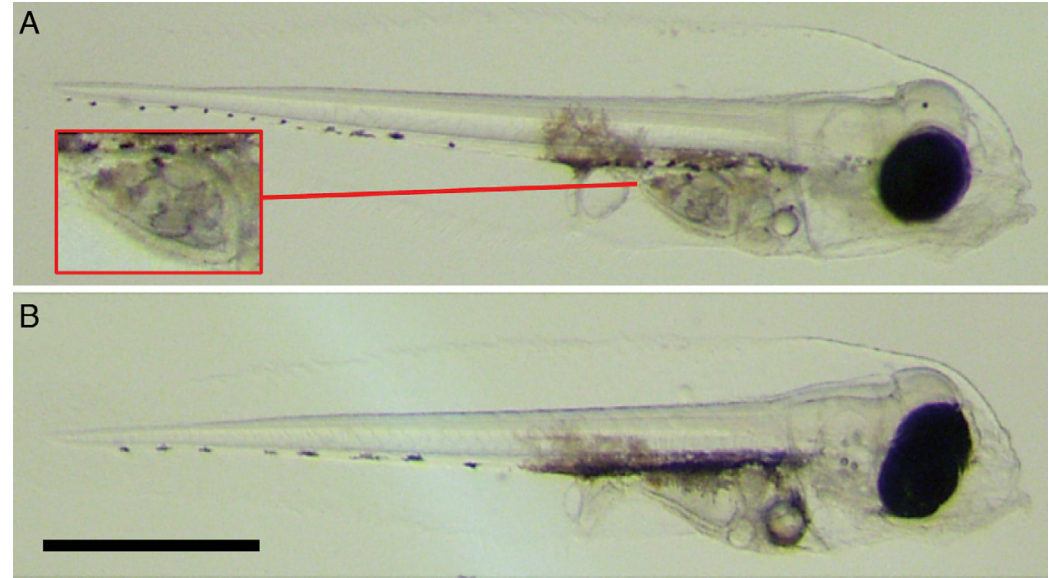

Fig. 1. Paracanthurus hepatus larvae 3 d post-hatch exhibiting (A) a gut filled with oyster veligers and (B) an empty gut. Scale bar $=500 \mu \mathrm{m}$

described in Section 2.2. Similarly, notochord length, body depth, eye diameter, and survival of $P$. hepatus were measured at $5 \mathrm{dph}$ as described in Section 2.2 .

\subsection{Effect of exposing oyster trochophores to acidic water on survival of $P$. hepatus}

During January 2019, fertilized eggs ( 12 h post-spawn) were transferred from the egg collector directly into sixteen 121 cylindrical black plastic tanks filled with $27^{\circ} \mathrm{C} \mathrm{FSW} \mathrm{at} \mathrm{a}$ density of 600 eggs $\operatorname{tank}^{-1}$. Tanks were set up as per Section 2.2, except there was no aeration. At $24 \mathrm{~h}$ post-

\subsection{Effects of oyster larval stage on growth and survival of $P$. hepatus}

The oyster trochophores developed to the veliger stage after $\sim 6 \mathrm{~h}$ in the experimental tanks, and, as veligers possess a calcified shell, this may have reduced their digestibility. To test whether different oyster larval stages varied in their quality as a feed for larval $P$. hepatus, we tested 3 diet treatments using the experimental tanks and setup described in Section 2.2, with 3 replicates treatment ${ }^{-1}$. The 3 diet treatments were oyster trochophores only, trochophores that were allowed to develop into veligers, and an unfed control. All tanks receiving oyster larvae were fed trochophores at a density of 15 trochophores $\mathrm{ml}^{-1}$ at the beginning of the light cycle. Tanks in the trochophore-only treatment were given 2 additional feeds of oyster trochophores 4 and $8 \mathrm{~h}$ after the beginning of the day cycle. Replicates receiving additional feeds were flushed for $2 \mathrm{~h}$ with $27^{\circ} \mathrm{C} \mathrm{FSW}$ at $0.251 \mathrm{~min}^{-1}$ prior to each feed, which removed $>90 \%$ of existing trochophores before they could develop into veligers. This flushing did not change the water temperature, $\mathrm{pH}$, or salinity compared to tanks that were not flushed. $N$. oculata was added during the water exchange to maintain the initial cell density. After flushing, the trochophores were restocked at a density of $15 \mathrm{ml}^{-1}$ using trochophores stored at $4^{\circ} \mathrm{C}$ as previously described. All other treatments received no water exchange during the light cycle. All tanks were flushed each night cycle with $27^{\circ} \mathrm{C} \mathrm{FSW} \mathrm{at} \mathrm{a} \mathrm{rate} \mathrm{of} 0.11 \mathrm{~min}^{-1}$ to remove all oyster larvae, algal cells, and waste. At 3 and 5 dph, prey incidence and gut area were measured as hatch, tanks were provided with $0.11 \mathrm{~min}^{-1}$ flowthrough FSW until $P$. hepatus larvae had developed the ability to feed exogenously at $3 \mathrm{dph}$. Water quality parameters during experiments were as per Section 2.2. The photoperiod was $16 \mathrm{~h}$ light:8 h dark, with a light intensity of $2000 \mathrm{~lx}$ at the level of the tanks.

A total of 60 ripe adult $S$. glomerata were sourced from a commercial producer at Urunga the day before the experiment and kept dry at room temperature $\left(\sim 20^{\circ} \mathrm{C}\right)$ to prevent spontaneous spawning. Each night prior to feeding, multiple female and male oysters were thermally induced to spawn ( $\mathrm{O}^{\prime}$ Connor et al. 2008) in individual $750 \mathrm{ml}$ plastic containers. Gametes were pooled, fertilised, and checked as per Section 2.2 and embryos were added to a 101 cylindro-conical culture tank containing gently aerated FSW $\left(\sim 25^{\circ} \mathrm{C}\right)$ for $\sim 8 \mathrm{~h}$ to develop to the trochophore stage. Oyster trochophores were washed in a $15 \mu \mathrm{m}$ wet sieve, counted, and transferred into four 11 cylindro-conical aerated bottles filled with FSW 2 containing $1.1 \times 10^{6}$ trochophores, and the other 2 containing $2.2 \times 10^{6}$ trochophores. Seawater in one bottle of each trochophore density was reduced to $\mathrm{pH} 4.8$ by addition of $8 \% \mathrm{HCl}$ solution. This $\mathrm{pH}$ was chosen as it rapidly deformed and ruptured trochophore integuments (Fig. 2), indicative of compromised shell calcification, without inducing mortality.

Bottles holding $1.1 \times 10^{6}$ trochophores were left at $\sim 25^{\circ} \mathrm{C}$ for $2 \mathrm{~h}$ before the being used for the day's first feed. Bottles containing $2.2 \times 10^{6}$ trochophores were held at $4^{\circ} \mathrm{C}$ for subsequent feeds that day. Oysters held at $4^{\circ} \mathrm{C}$ were acclimated at $\sim 27^{\circ} \mathrm{C}$ for 10 min prior to feeding. 


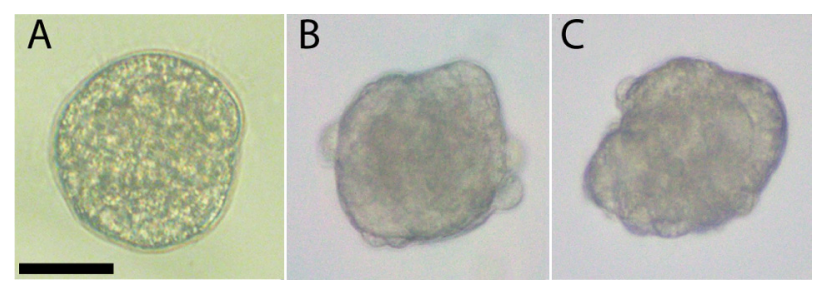

Fig. 2. Typical Saccostrea glomerata trochophores exposed to (A) ambient seawater, (B) $\mathrm{pH} 4.8$ seawater for $2 \mathrm{~h}$ and (C) $\mathrm{pH} 4.8$ seawater and refrigeration for $12 \mathrm{~h}$. Scale bar $=25 \mu \mathrm{m}$

To investigate whether exposing oyster trochophores to acidic water improved their quality as a feed for larval P. hepatus, we tested 3 diet treatments with 6 replicates treatment ${ }^{-1}$. The 3 diet treatments were oyster trochophores exposed to $\mathrm{pH} 4.8$ seawater, trochophores kept in ambient seawater ( $\mathrm{pH}$ 8.0-8.1), and an unfed control. All tanks were inoculated with live Chlorella like at a density of $3 \times 10^{5} \mathrm{cells} \mathrm{ml}^{-1}$. All tanks receiving oyster trochophores were fed at a density of 15 trochophores $\mathrm{ml}^{-1}$ at the beginning of the light cycle with 2 additional feeds at 5 and $10 \mathrm{~h}$ after the initial feed. All tanks were flushed for $2 \mathrm{~h}$ with $27^{\circ} \mathrm{C}$ FSW at $0.251 \mathrm{~min}^{-1}$ prior to each feed, which removed $>90 \%$ of trochophores before they developed into veligers. C. like was added during the water exchange to maintain the initial cell density. After flushing, trochophores were restocked at $15 \mathrm{ml}^{-1}$ using trochophores stored at $4^{\circ} \mathrm{C}$ as described in Section 2.3. All tanks were flushed each night cycle with $27^{\circ} \mathrm{C} \mathrm{FSW}$ at a rate of $0.21 \mathrm{~min}^{-1}$ to remove all oyster larvae, algal cells, and waste. Survival rates of $P$. hepatus larvae were determined at 5 and $10 \mathrm{dph}$ by counting the remaining fish in each replicate and reported as a percentage of the larvae initially stocked to each replicate tank.

\subsection{Statistical analysis}

Data for prey incidence, growth, and survival of larval $P$. hepatus were analysed using 1-way ANOVA in SPSS v24.0 with diet as a fixed factor. Normality and homoscedasticity were checked graphically using $\mathrm{P}-\mathrm{P}$ plots and plots of standardised residuals against predicted values. Data for prey incidence were not normally distributed or homoscedastic, and transforming the data did not have any effect, but given the nature of these data, this was expected. This should be taken into account when interpreting our prey incidence results. Tukey's HSD tests were used when ANOVA indicated there were significant differences among diet treatments $(p<0.05)$.

\section{RESULTS}

\subsection{Effects of live feeds on growth and survival of larval Paracanthurus hepatus}

At 3 and $5 \mathrm{dph},>75 \%$ of $P$. hepatus had prey in their gut when fed either oyster larvae alone or oyster larvae combined with rotifers (1-way ANOVA, $3 \mathrm{dph}$ : $F_{3,8}=81.22, \mathrm{p}<0.001 ; 5$ dph: $F_{3,8}=38.42, \mathrm{p}<0.001$; Figs. 1 \& 3). Up to $6.7 \%$ of $P$. hepatus fed rotifers had prey in their guts, while all unfed fish larvae had empty guts (Fig. 3A,B).

At $3 \mathrm{dph}$, the gut area of $P$. hepatus was larger in fish fed oyster larvae or oyster combined with rotifers compared to fish fed rotifers or unfed controls $\left(F_{3,8}=\right.$ $14.45, \mathrm{p}=0.001$; Fig. $3 \mathrm{C}$ ). At $5 \mathrm{dph}$, the gut area of $P$. hepatus fed oyster larvae was significantly larger than those fed rotifers or unfed controls $\left(F_{3,8}=6.96\right.$, $\mathrm{p}=0.013$; Fig. 3D). The gut area of $5 \mathrm{dph} P$. hepatus fed oyster larvae combined with rotifers was not different from all other treatments (Fig. 3D).

At $5 \mathrm{dph}$, there was no difference in the notochord length $\left(F_{3,8}=0.14, \mathrm{p}=0.93\right)$, body depth $\left(F_{3,8}=0.49, \mathrm{p}=\right.$ $0.70)$, or eye diameter $\left(F_{3,8}=1.95, \mathrm{p}=0.20\right)$ of $P$. hepatus among the 4 diet treatments.
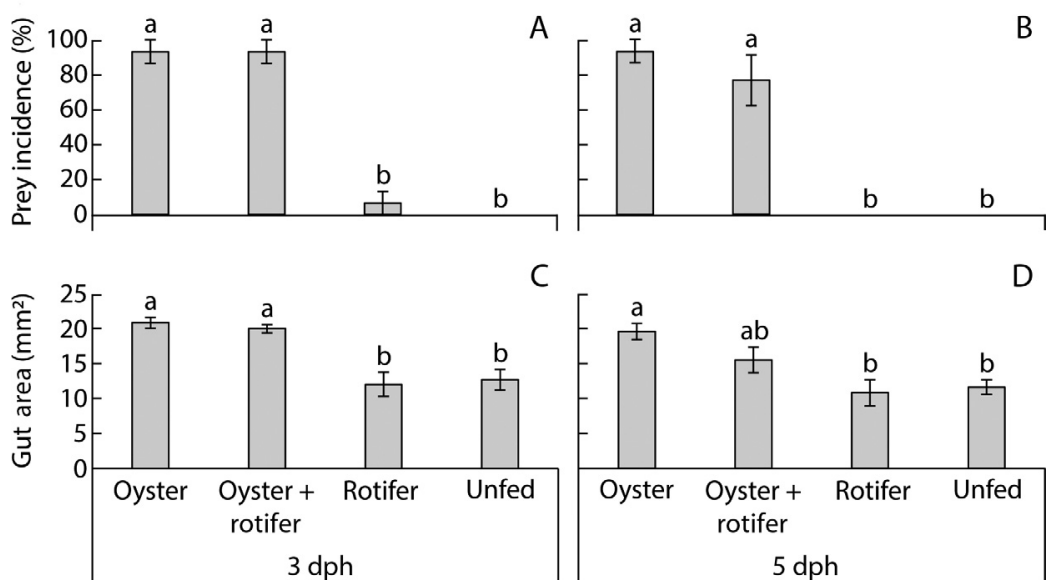

Fig. 3. Effects of diet on $(A, B)$ prey incidence and $(C, D)$ gut area of larval Paracanthurus hepatus at $(\mathrm{A}, \mathrm{C}) 3$ and $(\mathrm{B}, \mathrm{D}) 5 \mathrm{~d}$ post-hatch (dph). Prey incidence: the percentage of larvae with material in the digestive tract. Data are means \pm $\mathrm{SE}, \mathrm{n}=3$. Bars with the same letters are not significantly different according to 1 -way ANOVA followed by Tukey's HSD test $(\mathrm{p}<0.05)$ 


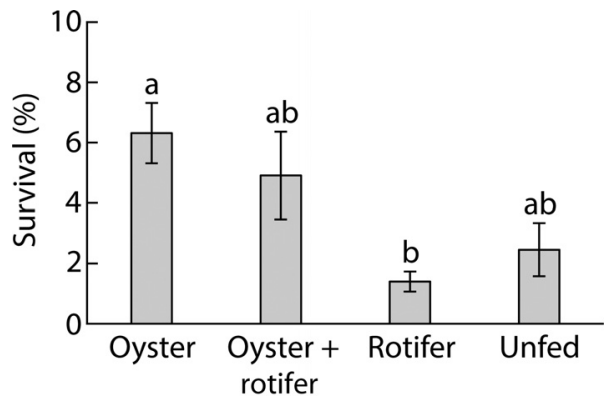

Fig. 4. Effect of diet on survival of Paracanthurus hepatus to 5 days post-hatch. Data are means $\pm \mathrm{SE}, \mathrm{n}=3$. Bars with the same letters are not significantly different according to 1-way ANOVA followed by Tukey's HSD test $(p<0.05)$

The survival rate of $5 \mathrm{dph} P$. hepatus fed exclusively oyster larvae $(\bar{X}=6.3 \%)$ was significantly greater than those fed only rotifers $(\bar{x}=1.4 \%)$ $\left(F_{3,8}=4.55, \mathrm{p}=0.039\right.$; Fig. 4). Survival of $P$. hepatus fed oyster larvae combined with rotifers $(\bar{X}=4.9 \%)$ or unfed controls $(\bar{x}=2.5 \%)$ was not different from all other treatments (Fig. 4).

\subsection{Effects of oyster larval stage on growth and survival of $P$. hepatus}

At 3 and $5 \mathrm{dph},>85 \%$ of $P$. hepatus larvae had prey in their guts when fed either only oyster trochophores or trochophores that developed into veligers, while all unfed fish had empty guts ( $3 \mathrm{dph}$ : $F_{2,6}=91.5, \mathrm{p}<0.001 ; 5$ dph: $F_{2,6}=41.52, \mathrm{p}<0.001$; Fig. 5A,B).
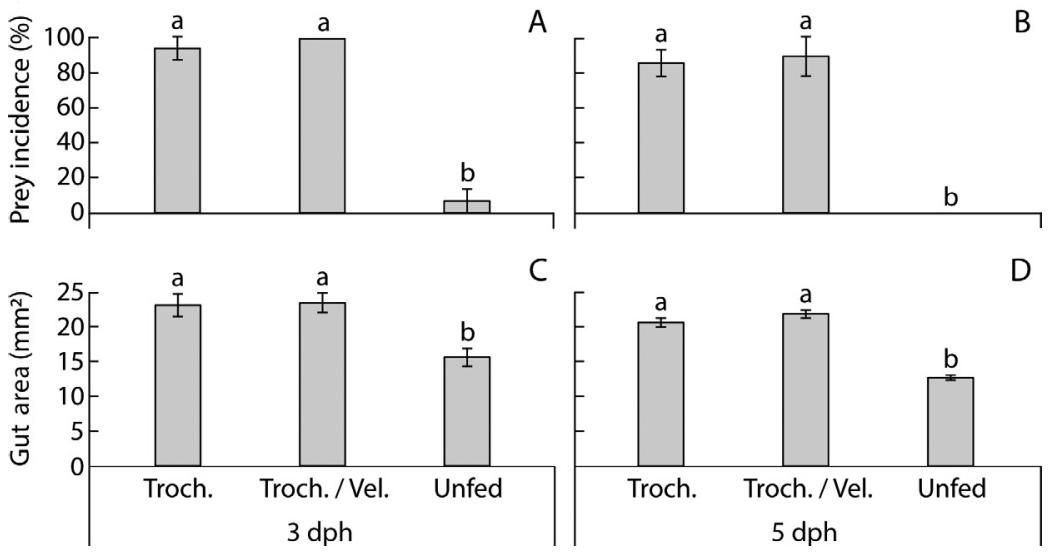

c

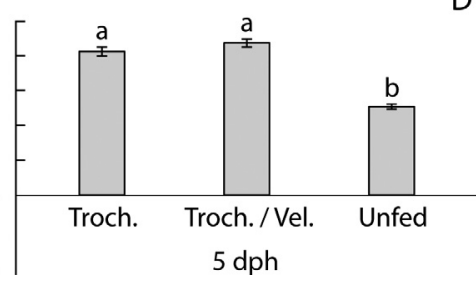

Fig. 5. Effects of diet on $(A, B)$ prey incidence and $(C, D)$ gut area of larval Paracanthurus hepatus at $(\mathrm{A}, \mathrm{C}) 3$ and $(\mathrm{B}, \mathrm{D}) 5$ days post-hatch (dph). Diets: oyster trochophores only (Troch.), oyster trochophores that developed into veligers during the feeding period (Troch./vel.), and unfed. Prey incidence is the percentage of larvae with material in the digestive tract. Data are means \pm $\mathrm{SE}, \mathrm{n}=3$. Bars with the same letters are not significantly different according to 1 -way ANOVA followed by Tukey's HSD test $(\mathrm{p}<0.05)$

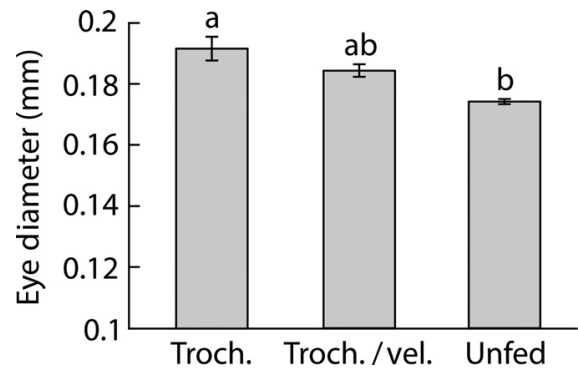

Fig. 6. Effects of diet on the eye diameter of larval Paracanthurus hepatus at 5 d post-hatch. See Fig. 5 for further details

At 3 and $5 \mathrm{dph}$, the gut areas of $P$. hepatus fed only oyster trochophores and trochophores that developed into veligers were not different from each other, but were significantly larger than unfed fish $(3 \mathrm{dph}$ : $F_{2,6}=9.34, \mathrm{p}=0.014 ; 5$ dph: $F_{2,6}=85.49, \mathrm{p}<0.001$; Fig. 5C,D).

There was no statistical difference in the notochord length $\left(F_{2,6}=0.88, \mathrm{p}=0.46\right)$ and body depth $\left(F_{2,6}=\right.$ $0.67, \mathrm{p}=0.55$ ) of $5 \mathrm{dph} P$. hepatus among any of the diet treatments. In contrast, the eye diameter of $P$. hepatus fed only oyster trochophores $(\bar{x}=0.191 \mathrm{~mm})$ was significantly wider than unfed $P$. hepatus $(\bar{x}=$ $0.174 \mathrm{~mm})\left(F_{2,6}=11.40, \mathrm{p}=0.009\right.$; Fig. 6$)$. The eye diameter of $P$. hepatus fed oyster trochophores that developed into veligers $(\bar{x}=0.184 \mathrm{~mm})$ did not differ from all other treatments (Fig. 6).

The survival rate of $5 \mathrm{dph} P$. hepatus fed only oyster trochophores $(\bar{x}=9.12 \%)$ was significantly higher than unfed fish $(\bar{x}=1.75 \%)\left(F_{2,6}=5.55, \mathrm{p}=0.043\right.$; Fig. 7). Survival of P. hepatus fed trochophores that developed into veligers $(\bar{X}=5.96 \%)$ was not different from any other treatment (Fig. 7).

\subsection{Effect of exposing oyster trochophores to acidic water on survival of $P$. hepatus}

At $5 \mathrm{dph}, P$. hepatus fed oyster trochophores exposed to $\mathrm{pH} 4.8$ seawater had significantly higher survival $(\bar{x}=$ $41.3 \%$ ) than those fed regular trochophores $(\bar{x}=13.4 \%)$, while unfed fish had significantly lower survival $(\bar{x}=2.6 \%)$ than all other treatments $\left(F_{2,15}=21.39, \mathrm{p}<0.001\right.$; Fig. $\left.8 \mathrm{~A}\right)$. At $10 \mathrm{dph}$, the only surviving treatment was $P$. hepatus fed oyster trochophores exposed to $\mathrm{pH} 4.8$ seawater $(\bar{x}=$ $0.33 \%$ survival; Fig. 8B). 


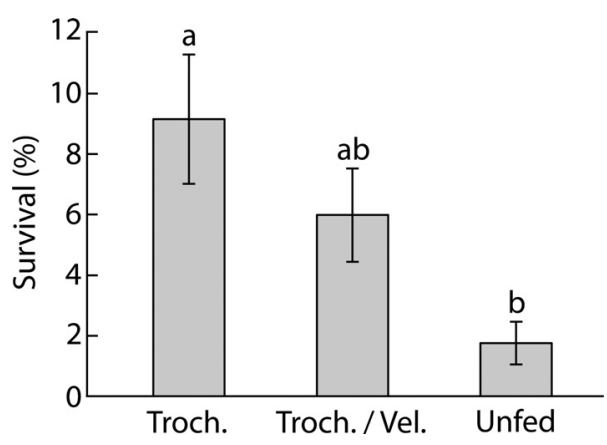

Fig. 7. Effect of diet on survival of Paracanthurus hepatus to 5 days post-hatch (dph). See Fig. 5 for further details
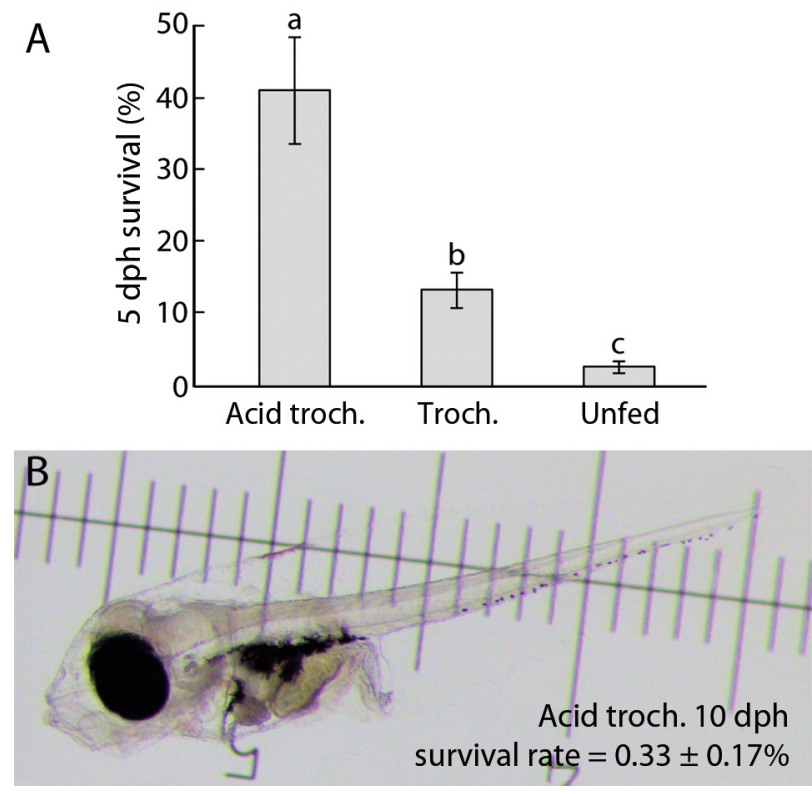

Fig. 8. Effect of diet on survival of Paracanthurus hepatus at (A) $5 \mathrm{~d}$ post-hatch (dph), and (B) image of $10 \mathrm{dph}$ P. hepatus with corresponding survival rate. Diets: oyster trochophores exposed to $\mathrm{pH} 4.8$ seawater (Acid troch.), regular oyster trochophores (Troch.), and unfed. Data are means \pm SE, $\mathrm{n}=6$. Bars with the same letters are not significantly different according to 1-way ANOVA followed by Tukey's HSD test $(\mathrm{p}<0.05)$

\section{DISCUSSION}

This study tested oyster Saccostrea glomerata larvae as a first feed for the commercially important ornamental fish Paracanthurus hepatus. We found that $P$. hepatus readily consumed oyster larvae, but almost never consumed rotifers. Survival and growth of $P$. hepatus larvae was poor when fed oyster trochophores that developed into veligers, possibly because veligers have an indigestible shell. The sur- vival of $P$. hepatus was better when fed oyster larvae only at the trochophore stage, and best when oyster trochophores had their calcification compromised in acidic water before being fed to the fish. Despite this promising result, few $P$. hepatus survived beyond 10 dph when fed oyster trochophores, possibly due to nutritional deficiencies. Improving the nutritional quality of oyster trochophores may improve their value as a live feed for larval marine fish.

In this study $P$. hepatus did not eat, and therefore did not survive, when fed rotifers. Rotifers are an established live feed for the larvae of many fish species (Conceição et al. 2010), but are unlikely to be suitable for fish larvae with small mouth gapes that require very small prey (Holt 2003, Moorhead \& Zeng 2010, Ho et al. 2013, but see Lee et al. 2018). The rotifers in this study were larger than the mouth gape of larval P. hepmtus (110-170 $\mu \mathrm{m}$; Nagano et al. 2000a, Ho et al. 2013) and were likely too large to be consumed by the early larval stages of $P$. hepatus. This result adds to the growing body of literature demonstrating the unsuitability of conventional live feeds for the small-mouthed larvae of many marine fish (Doi et al. 1997, Su et al. 2005, Moorhead \& Zeng 2010, DiMaggio et al. 2017).

Larval $P$. hepatus readily consumed oyster trochophores and veligers. The larvae of a wide range of fish species consume bivalve larvae when offered as a live feed during larviculture (Howell 1979, Harding 1999, Cabrera \& Hur 2001, Ma et al. 2013, Harding et al. 2015). Bivalve larvae are rarely found in the guts of wild oceanic fish larvae, probably because bivalves are rare in these environments (Llopiz 2013, Djurhuus et al. 2018). However, in estuaries where bivalves are common, larval fish frequently consume bivalve larvae (Harding 1999, Baker \& Mann 2003, Paolucci et al. 2007, Nack et al. 2015). It is likely that $P$. hepatus readily consumed oyster larvae because they were an appropriate size. Larval fish are thought to prefer prey size that is $25-60 \%$ of their mouth gape, and the oyster larvae we used were $\sim 30 \%$ of the mouth gape of $P$. hepatus (Shirota 1970, Fernández-Díaz et al. 1994, Cunha \& Planas 1999, Østergaard et al. 2005). The presence of rotifers did not appear to inhibit oyster larvae consumption, which indicates that larval $P$. hepatus, like other fish species, are able to select appropriately sized prey (Cunha \& Planas 1999, Yúfera \& Darias 2007).

The swimming behaviour of prey is an important factor in determining the rate at which they are captured and consumed by larval fish. Early studies suggested the conspicuous 'stop-start' movement of copepods was the reason that they are common in wild 
larval fish guts (Peterson \& Ausubel 1984, Buskey et al. 1993). However, recent research has found that because the early stages of many fish larvae have limited swimming and hunting abilities, they prefer slower-moving prey without predator escape responses (Turingan et al. 2005, Beck \& Turingan 2007, Robinson et al. 2019). Oyster larvae display a slow, almost continuous spiralling swimming pattern and were readily eaten by first-feeding $P$. hepatus. A wide spectrum of prey swimming behaviours have triggered successful feeding responses by $P$. hepatus (Lee et al. 2018). This supports the idea that fish larvae do not require that prey have a specific swimming action to trigger a feeding response, and a greater range of organisms than previously thought may be useful as live feeds (Bruno et al. 2018).

Although $P$. hepatus readily consumed oyster larvae, the growth and survival of $P$. hepatus fed oyster trochophores that subsequently developed into veligers was similar to unfed controls. This is similar to Lim (1993) and Cabrera \& Hur (2001), who observed poor growth and survival of fish larvae fed exclusively bivalve trochophores and veligers. Conversely, Howell (1979) found high survival (80\%) in Scophthalmus maximus larvae fed oyster veligers, although larval length and survival was greatest when their diet contained rotifers. The poor survival and growth of $P$. hepatus fed oyster larvae is likely due to the trochophores developing into indigestible shelled veligers (Lee et al. 2006, Ma et al. 2013, Nack et al. 2015). Supporting this, we observed intact veliger shells at the end of the digestive tract of larval $P$. hepatus (Fig. 1A). This problem could be mitigated by flushing veligers out of larval rearing systems and replacing them with newly developed trochophores, as is done with other live feeds when they have lost their nutritional value (Woolley et al. 2012).

We found that $P$. hepatus larvae fed only oyster trochophores, by flushing out oyster larvae before they developed to veligers, had significantly higher survival $(9.12 \%)$ than unfed controls $(1.75 \%)$ at $5 \mathrm{dph}$. This survival is still low relative to other species of similarly aged fish (Olivotto et al. 2006, Fielder \& Heasman 2011, Pereira-Davison \& Callan 2018), and all fish were dead by $7 \mathrm{dph}$. We observed that $P$. hepatus were unable to completely digest trochophores (Fig. 9A). While oyster trochophores are less calcified than veligers and do not have a shell, they do have calcified structures and are composed of about $8 \%$ aragonite (Lee et al. 2006). We suggest that the rudimentary gut of first-feeding $P$. hepatus is not capable of fully digesting prey with even minimal calcification. Calcification plays an important role in

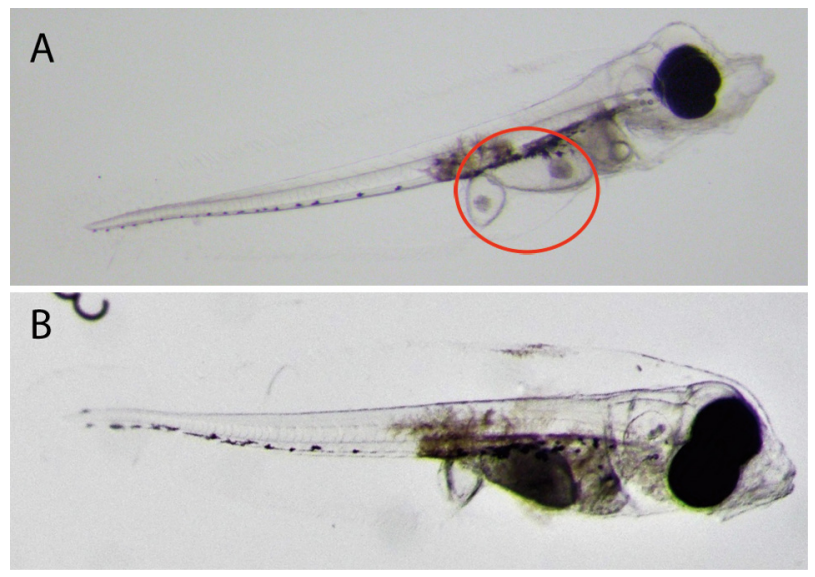

Fig. 9. (A) Saccostrea glomerata trochophores (circled) observed swimming in the digestive tract of a 3 day post-hatch (dph) Paracanthurus hepatus larvae. (B) 3 dph $P$. hepatus larvae fed oyster trochophores exposed to $\mathrm{pH} 4.8$ seawater. Digestion of trochophores is evidenced by lack of visible intact oysters and homogenous grey matter in the gut

determining the suitability of small invertebrate larvae as live feeds for larval fish.

$P$. hepatus larvae fed only oyster trochophores had significantly greater eye development than larvae that were unfed, but there was no difference in body length or depth of $P$. hepatus among any diet treatments. Eye development is important in larviculture, as it improves the vision and ability of larval fish to capture prey (Yúfera \& Darias 2007). Greater opsin protein concentrations and an associated increase in prey capture ability has been shown in 5 dph Thunnus thynnus fed diets high in docosahexanoic acid (DHA) (Koven et al. 2018). Bivalve larvae contain high proportions of PUFAs such as DHA, which may explain greater eye development by $P$. hepatus fed trochophores (Caers et al. 2002). However, a substantial increase in eye diameter is usually not seen as early as $P$. hepatus displayed in this study (Roo et al. 1999, Gisbert et al. 2002, Thépot et al. 2016). During the early larval stage, many fish instead prioritise body growth to improve swimming ability (Osse et al. 1997, Yúfera \& Darias 2007). Further research is required to understand why $P$. hepatus appears to prioritise growth in eye diameter instead of body size up to $5 \mathrm{dph}$.

$P$. hepatus fed oyster trochophores conditioned in $\mathrm{pH} 4.8$ seawater had higher survival compared to fish fed untreated trochophores. The survival rate of $5 \mathrm{dph}$ $P$. hepatus fed trochophores exposed to acidic water exceeds that of yellow tang Zebrasoma flavescens fed copepod nauplii to the same age (Pereira-Davison \& Callan 2018). While bivalve larvae have been 
previously tested as a live feed for fish larvae (Howell 1979, Lim 1993, Cabrera \& Hur 2001), this study is the first to use acidic water to compromise oyster trochophore calcification to improve its value as a live feed. Acidic conditions impact the ability of bivalve larvae to calcify and cause abnormalities (Parker et al. 2009, Gazeau et al. 2013). We chose pH 4.8, as it was the lowest $\mathrm{pH}$ oyster trochophores could tolerate and caused extreme deformities (Fig. 2). We observed that first-feeding $P$. hepatus were able to digest oyster trochophores exposed to $\mathrm{pH} 4.8$ seawater (Fig. 9B). Exposing oyster trochophores to $\mathrm{pH} 4.8$ seawater facilitated the survival of $P$. hepatus beyond the first-feeding period to $10 \mathrm{dph}$.

This study highlights the potential for oyster larvae to be used as a live feed for $P$. hepatus and possibly other fish larvae with small mouth gapes. Oyster larvae have the appropriate size and movement to illicit a feeding response by larval fish, challenging the paradigm that larval fish require live feeds like copepods that have a 'stop-start' swimming movement (Bruno et al. 2018). We were able to improve the digestibility of oyster trochophores by conditioning them in acidic seawater. The low survival of $P$. hepatus at 10 dph may be due to the oyster trochophores not providing the fish a nutritionally complete diet, but this requires further research. One method to improve larval fish survival may be to manipulate the diet of oyster broodstock to alter the nutritional profile of their larvae (see the Supplement at www.intres.com/articles/suppl/q011p657_supp.pdf) (Caers et al. 2002, Uriarte et al. 2004, González-Araya et al. 2012). Future studies should also investigate the biosecurity risks involved with using wild oyster offspring in intensive systems as well as costs associated with maintaining reproductive oyster broodstock yearround for commercial live feed production.

Acknowledgements. This study was approved by the Southern Cross University Animal Care and Ethics Committee (approval number 18/071). Financial support was provided by Mars Symbioscience (grant number 51647) and the Australian Government Research Training Program scholarship. We thank the 3 anonymous reviewers and contributing editor whose comments improved the manuscript.

\section{LITERATURE CITED}

Ajiboye OO, Yakubu AF, Adams TE, Olaji ED, Nwogu NA (2011) A review of the use of copepods in marine fish larviculture. Rev Fish Biol Fish 21:225-246

Alajmi F, Zeng C (2014) The effects of stocking density on key biological parameters influencing culture productivity of the calanoid copepod, Parvocalanus crassirostris. Aquaculture 434:201-207
Anderson DT, Anderson JT, Egan EA (1988) Balanoid barnacles of the genus Hexaminius (Archaeobalanidae: Elminiinae) from mangroves of New South Wales, including a description of a new species. Rec Aust Mus 40:205-223

* Baker P, Mann R (2003) Late stage bivalve larvae in a wellmixed estuary are not inert particles. Estuaries 26:837-845

* Barnes H, Barnes M (1959) The naupliar stages of Balanus nubilus Darwin. Can J Zool 37:15-23

Beck JL, Turingan RG (2007) The effects of zooplankton swimming behavior on prey-capture kinematics of red drum larvae, Sciaenops ocellatus. Mar Biol 151:1463-1470

Bellonio G, Lohrmann K, Dupré E (1993) Larval morphology of the scallop Argopecten purpuratus as revealed by scanning electron microscopy. Veliger 36:322-342

Bruno E, Højgaard JK, Hansen BW, Munk P, Støttrup JG (2018) Influence of swimming behavior of copepod nauplii on feeding of larval turbot (Scophthalmus maximus). Aquacult Int 26:225-236

Buskey EJ, Coulter C, Strom S (1993) Locomotory patterns of microzooplankton: potential effects on food selectivity of larval fish. Bull Mar Sci 53:29-43

* Cabrera T, Hur SB (2001) The nutritional value of live foods on the larval growth and survival of Japanese flounder, Paralichthys olivaceus. J Appl Aquacult 11:35-53

* Caers M, Utting S, Coutteau P, Millican P, Sorgeloos P (2002) Impact of the supplementation of a docosahexaenoic acid-rich emulsion on the reproductive output of oyster broodstock, Crassostrea gigas. Mar Biol 140: 1157-1166

Calado R (2017) The need for cultured specimens. In: Calado R, Olivotto I, Oliver MP, Holt GJ (eds) Marine ornamental species aquaculture. John Wiley \& Sons, Hoboken, NJ, p 15-22

Calado R, Olivotto I, Oliver MP, Holt GJ (eds) (2017) Marine ornamental species aquaculture. John Wiley \& Sons, Hoboken, NJ

Callan CK, Burgess AI, Rothe CR, Touse R (2018) Development of improved feeding methods in the culture of yellow tang, Zebrasoma flavescens. J World Aquacult Soc 49:493-503

Chigbu P, Suchar VA (2006) Isolation and culture of the marine rotifer, Colurella dicentra (Gosse, 1887), from a Mississippi Gulf Coast estuary. Aquacult Res 37:1400-1405

Chu FLE, Webb KL (1984) Polyunsaturated fatty acids and neutral lipids in developing larvae of the oyster, Crassostrea virginica. Lipids 19:815-820

* Cobcroft JM, Shu-Chien AC, Kuah MK, Jaya-Ram A, Battaglene SC (2012) The effects of tank colour, live food enrichment and greenwater on the early onset of jaw malformation in striped trumpeter larvae. Aquaculture 356-357:61-72

Conceição LE, Yúfera M, Makridis P, Morais S, Dinis MT (2010) Live feeds for early stages of fish rearing. Aquacult Res 41:613-640

* Cunha I, Planas M (1999) Optimal prey size for early turbot larvae (Scophthalmus maximus L.) based on mouth and ingested prey size. Aquaculture 175:103-110

Dahms HU (1993) Pictorial keys for the identification of crustacean nauplii from the marine meiobenthos. J Crustac Biol 13:609-616

*Dahms HU, Lorenzen S, Schminke HK (1991) Phylogenetic relationships within the taxon Tisbe (Copepoda, Harpacticoida) as evidenced by naupliar characters. J Zool Syst Evol Res 29:450-465

* Davis HC, Chanley PE (1956) Spawning and egg production 
of oysters and clams. Biol Bull (Woods Hole) 110:117-128 de Freitas Côrtes G, Tsuzuki MY, Melo EMC (2013) Monoculture of the ciliate protozoan Euplotes sp. (Ciliophora; Hypotrichia) fed with different diets. Acta Sci Biol Sci 35: 15-19

De la Roche JP, Marín B, Freites L, Vélez A (2002) Embryonic development and larval and post-larval growth of the tropical scallop Nodipecten (=Lyropecten) nodosus (L. 1758) (Mollusca: Pectinidae). Aquacult Res 33:819-827

*Dhont J, Dierckens K, Støttrup J, Van Stappen G, Wille M, Sorgeloos P (2013) Rotifers, Artemia and copepods as live feeds for fish larvae in aquaculture. In: Allan G, Burnell G (eds) Advances in aquaculture hatchery technology. Woodhead Publishing, Sawston, p 157-202.

*DiMaggio MA, Cassiano EJ, Barden KP, Ramee SW, Ohs CL, Watson CA (2017) First record of captive larval culture and metamorphosis of the Pacific blue tang, Paracanthurus hepatus. J World Aquacult Soc 48:393-401

Djurhuus A, Pitz K, Sawaya NA, Rojas Márquez J and others (2018) Evaluation of marine zooplankton community structure through environmental DNA metabarcoding. Limnol Oceanogr Methods 16:209-221

Doi M, Toledo JD, Golez MSN, de los Santos M, Ohno A (1997) Preliminary investigation of feeding performance of larvae of early red-spotted grouper, Epinephelus coioides, reared with mixed zooplankton. Hydrobiologia 358:259-263

Doroudi MS, Southgate PC (2003) Embryonic and larval development of Pinctada margaritifera (Linnaeus, 1758). Molluscan Res 23:101-107

Egan EA, Anderson DT (1988) Larval development of the coronuloid barnacles Austrobalanus imperator (Darwin), Tetraclitella purpurascens (Wood) and Tesseropora rosea (Krauss) (Cirripedia, Tetraclitidae). J Nat Hist 22:1379-1405

Fernández-Díaz C, Pascual E, Yúfera M (1994) Feeding behaviour and prey size selection of gilthead seabream, Sparus aurata, larvae fed on inert and live food. Mar Biol 118:323-328

Fielder DS, Heasman M (2011) Hatchery manual for the production of Australian bass, mulloway and yellowtail kingfish. NSW Department of Primary Industries, Port Stephens Fisheries Institute

Fisher R, Sogard SM, Berkeley SA (2007) Trade-offs between size and energy reserves reflect alternative strategies for optimizing larval survival potential in rockfish. Mar Ecol Prog Ser 344:257-270

Franco SC, Augustin CB, Geffen AJ, Dinis MT (2017) Growth, egg production and hatching success of Acartia tonsa cultured at high densities. Aquaculture 468:569-578

Gallager SM, Mann R (1986) Growth and survival of larvae of Mercenaria mercenaria (L.) and Crassostrea virginica (Gmelin) relative to broodstock conditioning and lipid content of eggs. Aquaculture 56:105-121

* Gazeau F, Gattuso JP, Dawber C, Pronker AE and others (2010) Effect of ocean acidification on the early life stages of the blue mussel Mytilus edulis. Biogeosciences 7:2051-2060

Gazeau F, Parker LM, Comeau S, Gattuso JP and others (2013) Impacts of ocean acidification on marine shelled molluscs. Mar Biol 160:2207-2245

Gisbert E, Merino G, Muguet JB, Bush D, Piedrahita RH, Conklin DE (2002) Morphological development and allometric growth patterns in hatchery-reared California halibut larvae. J Fish Biol 61:1217-1229
González-Araya R, Mingant C, Petton B, Robert R (2012) Influence of diet assemblage on Ostrea edulis broodstock conditioning and subsequent larval development. Aquaculture 364-365:272-280

*Hagiwara A, Suga K, Akazawa A, Kotani T, Sakakura Y (2007) Development of rotifer strains with useful traits for rearing fish larvae. Aquaculture 268:44-52

*Hamre K, Srivastava A, Rønnestad I, Mangor-Jensen A, Stoss J (2008) Several micronutrients in the rotifer Brachionus sp. may not fulfil the nutritional requirements of marine fish larvae. Aquacult Nutr 14:51-60

* Hamre K, Yúfera M, Rønnestad I, Boglione C, Conceição LE, Izquierdo $M$ (2013) Fish larval nutrition and feed formulation: knowledge gaps and bottlenecks for advances in larval rearing. Rev Aquacult 5:S26-S58

*Harding JM (1999) Selective feeding behavior of larval naked gobies Gobiosoma bosc and blennies Chasmodes bosquianus and Hypsoblennius hentzi: preferences for bivalve veligers. Mar Ecol Prog Ser 179:145-153

* Harding JM, Allen DM, Dingley S, Tremont RM, Krug SM, Armstrong CT (2015) Ontogenetic changes in predator-prey interactions between two species of larval fishes and oyster veligers. J Exp Mar Biol Ecol 471: 164-174

Helm MM, Bourne N, Lovatelli A (2004) Hatchery culture of bivalves: a practical manual. FAO Fish Tech Pap No. 471. FAO, Rome

Ho YS, Lee PS, Cheng MJ, Jiang YY, Chen WY (2013) Artificial propagation of palette surgeonfish (Paracanthurus hepatus). J Taiwan Fish Res 21:83-95

Holt GJ (2003) Research on culturing the early life history stages of marine ornamental species. In: Cato JC, Brown CL (eds) Marine ornamental species: collection, culture and conservation. Iowa State Press, Ames, IA, p 251-254

Howell BR (1979) Experiments of the rearing of larval turbot, Scophthalmus maximus L. Aquaculture 18:215-225

$\mathrm{Hu}$ C, Li H, Xia J, Zhang L and others (2013) Spawning, larval development and juvenile growth of the sea cucumber Stichopus horrens. Aquaculture 404-405:47-54

* Jakobsen HH, Hansen PJ (1997) Prey size selection, grazing and growth response of the small heterotrophic dinoflagellate Gymnodinium sp. and the ciliate Balanion comatum-a comparative study. Mar Ecol Prog Ser 158:75-86

Jameson SC (1976) Early life history of the giant clams Tridacna crocea Lamarck, Tridacna maxima (Roding), and Hippopus hippopus (Linnaeus). Pac Sci 30:219-233

Jeong HJ, Latz MI (1994) Growth and grazing rates of the heterotrophic dinoflagellates Protoperidinium spp. on red tide dinoflagellates. Mar Ecol Prog Ser 106:173-185

Johnson MW, Olson JB (1948) The life history and biology of a marine harpacticoid copepod, Tisbe furcata (Baird). Biol Bull 95:320-332

* Jonsson PR (1986) Particle size selection, feeding rates and growth dynamics of marine planktonic oligotrichous ciliates (Ciliophora: Oligotrichina). Mar Ecol Prog Ser 33: 265-277

Karlsen Ø, van der Meeren T, Rønnestad I, Mangor-Jensen A, Galloway TF, Kjørsvik E, Hamre K (2015) Copepods enhance nutritional status, growth and development in Atlantic cod (Gadus morhua L.) larvae-Can we identify the underlying factors? PeerJ 3:e902

Kimani EN (1996) The larval development and juvenile growth of the silvermouth turban, Turbo argyrostomus L. 1758 (Mollusca: Prosobranchia). Asian Mar Biol 13: 105-116 
Kline MD, Laidley CW (2015) Development of intensive copepod culture technology for Parvocalanus crassirostris: optimizing adult density. Aquaculture 435:128-136

Korn OM (1991) Larvae of the barnacle Balanus improvisus in the Sea of Japan. Biol Mora (Vladivost) 1:52-62

Koven W, Nixon O, Allon G, Gaon A and others (2018) The effect of dietary DHA and taurine on rotifer capture success, growth, survival and vision in the larvae of Atlantic bluefin tuna (Thunnus thynnus). Aquaculture 482:137-145

Kurihara H, Asai T, Kato S, Ishimatsu A (2008) Effects of elevated $\mathrm{pCO}_{2}$ on early development in the mussel Mytilus galloprovincialis. Aquat Biol 4:225-233

* Lamare M, Harianto J, Uthicke S, Agüera A and others (2018) Larval thermal windows in native and hybrid Pseudoboletia progeny (Echinoidea) as potential drivers of the hybridization zone. Mar Ecol Prog Ser 598: 99-112

Langdon C (2003) Microparticle types for delivering nutrients to marine fish larvae. Aquaculture 227:259-275

Lecchini D, Polti S, Nakamura Y, Mosconi P, Tsuchiya M, Remoissenet G, Planes S (2006) New perspectives on aquarium fish trade. Fish Sci 72:40-47

Lee SW, Hong SM, Choi CS (2006) Characteristics of calcification processes in embryos and larvae of the Pacific oyster, Crassostrea gigas. Bull Mar Sci 78:309-317

* Lee IS, Ohs CL, Broach JS, DiMaggio MA, Watson CA (2018) Determining live prey preferences of larval ornamental marine fish utilizing fluorescent microspheres. Aquaculture 490:125-135

Leu MY, Sune YH, Meng PJ (2015) First results of larval rearing and development of the bluestriped angelfish Chaetodontoplus septentrionalis (Temminck \& Schlegel) from hatching through juvenile stage with notes on its potential for aquaculture. Aquacult Res 46:1087-1100

Lewis CA (1975) Development of the gooseneck barnacle Pollicipes polymerus (Cirripedia: Lepadomorpha): fertilization through settlement. Mar Biol 32:141-153

Lim LC (1993) Larviculture of the greasy grouper Epinephelus tauvina $\mathrm{F}$. and the brown-marbled grouper $E$. fuscoguttatus F. in Singapore. J World Aquacult Soc 24: $262-274$

Llopiz JK (2013) Latitudinal and taxonomic patterns in the feeding ecologies of fish larvae: a literature synthesis. J Mar Syst 109-110:69-77

Ma Z, Guo H, Zhang N, Bai Z (2013) State of art for larval rearing of grouper. Int J Aquacult 3:63-72

* Marsden JR, Anderson DT (1981) Larval development and metamorphosis of the serpulid polychaete Galeolaria caespitosa Lamarck. Mar Freshw Res 32:667-680

Massapina C, Joaquim S, Matias D, Devauchelle N (1999) Oocyte and embryo quality in Crassostrea gigas (Portuguese strain) during a spawning period in Algarve, South Portugal. Aquat Living Resour 12:327-333

* McKinnon AD, Duggan S, Nichols PD, Rimmer MA, Semmens G, Robino B (2003) The potential of tropical paracalanid copepods as live feeds in aquaculture. Aquaculture 223:89-106

Mies M, Braga F, Scozzafave MS, Lemos DELD, Sumida PYG (2012) Early development, survival and growth rates of the giant clam Tridacna crocea (Bivalvia: Tridacnidae). Braz J Oceanogr 60:127-133

Militz TA, Foale S (2017) The 'Nemo effect': perception and reality of Finding Nemo's impact on marine aquarium fisheries. Fish Fish 18:596-606
Miller KM, Roughgarden J (1994) Descriptions of the larvae of Tetraclita rubescens and Megabalanus californicus with a comparison of the common barnacle larvae of the central California coast. J Crustac Biol 14:579-600

Miller TJ, Crowder LB, Rice JA, Marschall EA (1988) Larval size and recruitment mechanisms in fishes: toward a conceptual framework. Can J Fish Aquat Sci 45:1657-1670

*Miller KM, Blower SM, Hedgecock D, Roughgarden J (1989) Comparisons of larval and adult stages of Chthamalus dalli and Chthamalus fissus (Cirripedia: Thoracica). J Crustac Biol 9:242-256

*Montagnes DJS, Berger JD, Taylor FJR (1996) Growth rate of the marine planktonic ciliate Strombidinopsis cheshiri Snyder and Ohman as a function of food concentration and interclonal variability. J Exp Mar Biol Ecol 206:121-132

* Moorhead JA, Zeng C (2010) Development of captive breeding techniques for marine ornamental fish: a review. Rev Fish Sci 18:315-343

Nack CC, Limburg KE, Schmidt RE (2015) Diet composition and feeding behavior of larval American shad, Alosa sapidissima (Wilson), after the introduction of the invasive zebra mussel, Dreissena polymorpha (Pallas), in the Hudson River estuary, NY. Northeast Nat (Steuben) 22:437-450

Nagano N, Iwatsuki Y, Kamiyama T, Nakata H (2000a) Effects of marine ciliates on survivability of the first-feeding larval surgeonfish, Paracanthurus hepatus: laboratory rearing experiments. Hydrobiologia 432:149-157

Nagano N, Iwatsuki Y, Kamiyama T, Shimizu H, Nakata H (2000b) Ciliated protozoans as food for first-feeding larval grouper, Epinephelus septemfasciatus: laboratory experiment. Plankton Biol Ecol 47:93-99

O'Connor WA, O'Connor SJ (2011) Early ontogeny of the pipi, Donax (Plebidonax) deltoides (Donacidae; Bivalvia). Molluscan Res 31:53-56

O'Connor WA, Dove MC, Finn B, O'Connor SJ (2008) Manual for hatchery production of Sydney rock oysters (SaCcostrea glomerata). Final report to Fisheries Research and Development Corporation, Deakin, ACT, Australia. New South Wales Department of Primary IndustriesFisheries Research Report Series, 20, Cronulla

Oliver MP, Olivotto I, Turchi C (2017) Live prey production systems. In: Calado R, Olivotto I, Oliver MP, Holt GJ (eds) Marine ornamental species aquaculture. John Wiley \& Sons, Hoboken, NJ, p 111-124.

* Olivotto I, Zenobi A, Rollo A, Migliarini B, Avella M, Carnevali O (2005) Breeding, rearing and feeding studies in the cleaner goby Gobiosoma evelynae. Aquaculture 250:175-182

Olivotto I, Rollo A, Sulpizio R, Avella M, Tosti L, Carnevali O (2006) Breeding and rearing the sunrise dottyback Pseudochromis flavivertex: the importance of live prey enrichment during larval development. Aquaculture 255: 480-487

Olivotto I, Buttino I, Borroni M, Piccinetti CC, Malzone MG, Carnevali O (2008) The use of the Mediterranean calanoid copepod Centropages typicus in yellowtail clownfish (Amphiprion clarkii) larviculture. Aquaculture 284:211-216

Olivotto I, Oliver MP, Turchi C (2017) Larval diets and nutrition. In: Calado R, Olivotto I, Oliver MP, Holt GJ (eds) Marine ornamental species aquaculture. John Wiley \& Sons, Hoboken, NJ, p 125-138.

\% Osse JWM, Van den Boogaart JGM, Van Snik GMJ, Van der Sluys L (1997) Priorities during early growth of fish larvae. Aquaculture 155:249-258 
Østergaard P, Munk P, Janekarn V (2005) Contrasting feeding patterns among species of fish larvae from the tropical Andaman Sea. Mar Biol 146:595-606

*Paik SG, Park HS, Yi SK, Yun SG (2005) Developmental duration and morphology of the sea star Asterias amurensis, in Tongyeong, Korea. Ocean Sci J 40:65-70

Paolucci EM, Cataldo DH, Fuentes CM, Boltovskoy D (2007) Larvae of the invasive species Limnoperna fortunei (Bivalvia) in the diet of fish larvae in the Paraná River, Argentina. Hydrobiologia 589:219-233

Parker LM, Ross PM, O'Connor WA (2009) The effect of ocean acidification and temperature on the fertilization and embryonic development of the Sydney rock oyster Saccostrea glomerata (Gould 1850). Glob Change Biol 15:2123-2136

Pepin P (1991) Effect of temperature and size on development, mortality, and survival rates of the pelagic early life history stages of marine fish. Can J Fish Aquat Sci 48:503-518

Pereira-Davison E, Callan CK (2018) Effects of photoperiod, light intensity, turbidity and prey density on feed incidence and survival in first feeding yellow tang (Zebrasoma flavescens) (Bennett). Aquacult Res 49:890-899

Peterson WT, Ausubel SJ (1984) Diets and selective feeding by larvae of Atlantic mackerel Scomber scombrus on zooplankton. Mar Ecol Prog Ser 17:65-75

Ramofafia C, Byrne M, Battaglene C (2003) Reproduction of the commercial sea cucumber Holothuria scabra (Echinodermata: Holothuroidea) in the Solomon Islands. Mar Biol 142:281-288

Rhyne AL, Tlusty MF, Szczebak JT, Holmberg RJ (2017) Expanding our understanding of the trade in marine aquarium animals. PeerJ 5:e2949

Robinson HE, Strickler JR, Henderson MJ, Hartline DK, Lenz PH (2019) Predation strategies of larval clownfish capturing evasive copepod prey. Mar Ecol Prog Ser 614:125-146

Rønnestad I, Yúfera M, Ueberschär B, Ribeiro L, Saele Ø, Boglione C (2013) Feeding behaviour and digestive physiology in larval fish: current knowledge, and gaps and bottlenecks in research. Rev Aquacult 5:S59-S98

Roo FJ, Socorro J, Izquierdo MS, Caballero MJ, HernándezCruz CM, Fernández A, Fernández-Palacios H (1999) Development of red porgy Pagrus pagrus visual system in relation with changes in the digestive tract and larval feeding habits. Aquaculture 179:499-512

Rose RA, Baker SB (1994) Larval and spat culture of the Western Australian silver- or goldlip pearl oyster, Pinctada maxima Jameson (Mollusca: Pteriidae). Aquaculture 126:35-50

Rose RA, Dix TG (1984) Larval and juvenile development of the doughboy scallop, Chlamys (Chlamys) asperrimus (Lamarck) (Mollusca: Pectinidae). Mar Freshw Res 35: 315-323

Rose RA, Campbell GR, Sanders SG (1988) Larval development of the saucer scallop Amusium balloti (Bernardi) (Mollusca: Pectinidae). Mar Freshw Res 39:153-160

Sastry AN (1965) The development and external morphology of pelagic larval and post-larval stages of the bay scallop, Aequipecten irradians concentricus Say, reared in the laboratory. Bull Mar Sci 15:417-435

* Shirota A (1970) Studies on the mouth size of fish larvae. Bull Jpn Soc Sci Fish 36:353-369

Soudant P, Van Ryckeghem K, Marty Y, Moal J, Samain JF, Sorgeloos P (1999) Comparison of the lipid class and fatty acid composition between a reproductive cycle in nature and a standard hatchery conditioning of the Pacific oyster Crassostrea gigas. Comp Biochem Physiol B 123:209-222

Southgate PC (2012) Foods and feeding. In: Lucas JS, Southgate PC (eds) Aquaculture: farming aquatic animals and plants, $2^{\text {nd }}$ edn. Blackwell Publishing, Oxford, p 188-213.

Støttrup JG (2000) The elusive copepods: their production and suitability in marine aquaculture. Aquacult Res 31: 703-711

* Su HM, Cheng SH, Chen TI, Su MS (2005) Culture of copepods and applications to marine finfish larval rearing in Taiwan. In: Lee CS, O'Bryen PJ, Marcus NH (eds) Copepods in aquaculture. John Wiley \& Sons, Hoboken, NJ, p 183-194

* Thépot V, Mangott A, Pirozzi I (2016) Rotifers enriched with a mixed algal diet promote survival, growth and development of barramundi larvae, Lates calcarifer (Bloch). Aquacult Rep 3:147-158

Turingan RG, Beck JL, Krebs JM, Licamele JD (2005) Development of feeding mechanics in marine fish larvae and the swimming behavior of zooplankton prey: implications for rearing marine fishes. In: Lee CS, O'Bryen PJ, Marcus NH (eds) Copepods in aquaculture. John Wiley \& Sons, Hoboken, NJ, p 119-132

* Uriarte I, Farías A, Hernandez J, Schäfer C, Sorgeloos P (2004) Reproductive conditioning of Chilean scallop (Argopecten purpuratus) and the Pacific oyster (Crassostrea gigas): effects of enriched diets. Aquaculture 230:349-357

*Verity PG (1985) Grazing, respiration, excretion, and growth rates of tintinnids. Limnol Oceanogr 30:1268-1282

*Watanabe WO, Ellis SC, Ellis EP, Lopez VG, Bass P, Ginoza J, Moriwake A (1996) Evaluation of first feeding regimens for larval Nassau grouper Epinephelus straitus and preliminary, pilot scale culture through metamorphosis. J World Aquacult Soc 27:323-331

*Woolley LD, Partridge GJ, Qin JG (2012) Mortality reduction in yellowtail kingfish (Seriola lalandi) larval rearing by optimising Artemia feeding regimes. Aquaculture 344349:161-167

*Wullur S, Sakakura Y, Hagiwara A (2009) The minute monogonont rotifer Proales similis de Beauchamp: culture and feeding to small mouth marine fish larvae. Aquaculture 293:62-67

Young CM, Sewell MA, Rice ME (eds) (2002) Atlas of marine invertebrate larvae. Academic Press, New York, NY

* Yúfera M, Darias MJ (2007) The onset of exogenous feeding in marine fish larvae. Aquaculture 268:53-63

Z Zeng C, Shao L, Ricketts A, Moorhead J (2018) The importance of copepods as live feed for larval rearing of the green mandarin fish Synchiropus splendidus. Aquaculture 491:65-71

Submitted: May 17, 2019 ; Accepted: October 7, 2019

Proofs received from author(s): December 3, 2019
Editorial responsibility: Chris Noble,

Tromsø, Norway 